[Agr. Biol. Chem., Vol. 31, No. 8, p. 902 907, 1967]

\title{
Enzymatic Conversion of D-Glucose to D-Fructose
}

\author{
Part VIII. Propagation of Streptomyces phaeochromogenus \\ in the Presence of Cobaltous Ion*
}

\author{
By Nobuzo Tsumura, Masakatsu Hagi and Tomotaro SAto \\ Food Research Institute, Ministry of Agriculture and Forestry, Tokyo \\ Received March 17, 1967
}

\begin{abstract}
Propagation of Streptomyces phaeochromogenus by both shaking and submerged cultivations is described. The addition of $\mathrm{Co}^{++}$to medium remarkably improved the activity of the cell to convert glucose into fructose. The cell grown with $\mathrm{Co}^{++}$isomerized glucose at $\mathrm{pH}$ 9.0 and 7.5 similarly, whereas the cells grown without $\mathrm{Co}^{++}$reacted with glucose at $\mathrm{pH}$ 9.3 as the optimum. In submerged cultivation, the mode of $\mathrm{pH}$ change during cultivation period varied depending on the kind of strain, carbon source and the presence of $\mathrm{Co}^{+++}$.

In the propagation of the strain SK, carbon and nitrogen sources were rather rapidly consumed resulting in cell growth, when $\mathrm{pH}$ value of the medium was falling. On the other hand, however, growth hardly developed at the $\mathrm{pH}$ values lower than 6.0.

Therefore, it was necessary to adjust $\mathrm{pH}$ with alkali in order to get active cell yield.
\end{abstract}

The authors previously reported on the enzyme from Streptomyces phaeochromogenus, Strain SK, which catalyzes the conversion of D-glucose to D-fructose. ${ }^{1,21}$

In the course of studies on the cultivation method of the strain, it was found that the enzyme of the cells grown in the presence of cobaltous ion had a stronger heat stability and a wider $\mathrm{pH}$ range for activity than the enzyme produced without added cobaltous ion. Yamanaka ${ }^{3 \prime}$ already described the supplemental effect of cobaltous ion to manganese in the production of glucose-isomerizing enzyme from heterolactic acid bacteria. In the case of the author's microoganism, cobaltous ion showed a supplemental effect to magnesium. In this paper, the propagation of Streptomyces phaeochromogenus, as the enzyme

* Presented at the Annual Meeting of Agr. Chem. Soc. Japan, April, 1965, and April, 1966.

1) N. Tsumura and T. Sato, This Journal, 29, 1129 (1965)

2) N. Tsumura, E. Sakakura, M. Ishikawa and T. Sato, J. Ferm. Assoc., Japan, 23, 32 (1965).

3) K. Yamanaka, This Journal, 27, 265 (1963). sourse, in the presence of cobaltous ion, by shaking cultivation in flask and by aeration with agitation in a jar fermenter is described.

\section{METHODS}

\section{Strain, Medium and Cultivation Methods}

Strain. Streptomyces phaeochromogenus, strain SK and strain No. 3105**. The strain SK was mainly used unless otherwise mentioned.

Basal constituents. Xylose, $1 \%$; peptone, 1\%; meat extract, $0.5 \%$; yeast extract, $0.25 \%$; $\mathrm{NaCl}$. $0.5 \% ; \mathrm{MgSO}_{4} \cdot 7 \mathrm{H}_{2} \mathrm{O}, 0.05 \%$; in water.

Shaking cultivation. The cells from potato agar slant were inoculated into $100 \mathrm{ml}$ of the basal medium in $500-\mathrm{ml}$ Sakaguchi flask and incubated for 24 hours with shaking at $28^{\circ} \sim 30^{\circ} \mathrm{C}$. Then $2 \mathrm{ml}$ of the broth was added as the seed to $100 \mathrm{ml}$ of the medium containing the basal constituents plus $\mathrm{CoCl}_{2}$ at $10^{-3} \mathrm{M} / 1$. After 24 hours of shaking, cells were harvested by a refrigerated centrifuge and washed.

Cultivation in jar fermenter. Cells grown in the basal medium for 24 hours with shaking were used as the seed and the amount of inoculum was

** Given by the courtesy of the Institute for Fermentation, Osaka, Japan. 
$4 \%$ of main cultivation medium. The composition of main cultivation medium was identical to the basal medium except xylose was partly replaced with glucose and $\mathrm{CoCl}_{2}$ at $10^{-8} \mathrm{mols} / 1$ was added. After cultivation with controlled aeration and agitation at $28^{\circ} \sim 30^{\circ} \mathrm{C}$, the broth was cooled to $4 \sim 10^{\circ} \mathrm{C}$ with ice and then spun down by continuous centrifuge at about 12,000 r.p.m. The time required to separate $15 \mathrm{l}$ of the broth was about 1 hour.

\section{Assay Method}

Cell yield. Dried matter of cell suspension was measured similarty as in the previous paper ${ }^{2)}$ and cell yield was expressed by the dry substance from $100 \mathrm{ml}$ of the broth.

Activity. Enzyme activity of the cell was followed by the determination of fructose formed in the reaction mixture. The mixture consisted of $0.8 \mathrm{M}$ glucose, $0.01 \mathrm{M} \mathrm{MgSO}_{4}, 0.05 \mathrm{M}$ buffer (phosphate buffer, $\mathrm{pH}$ 7.5 , or ammonium buffer, $\mathrm{pH} 9.0), 12.5 \mathrm{mg} / \mathrm{ml}$ of cell (as dry matter) in final concentration and was incubated for 3 hours at $60^{\circ} \mathrm{C}$. Enzyme activity was expressed as the amount of fructose $(\mathrm{mg} / \mathrm{ml}$ of the reaction mixture) produced under the above conditions.

Xylose and nitrogen. Xylose and nitrogen contents in the medium were measured by the Bial reaction ${ }^{4)}$ and by Kjeldahl's method, respectively.

pH. pH value of culivation medium was determined with glass-electrode $\mathrm{pH}$ meter.

\section{RESULTS AND DISCUSSION}

\section{Shaking Cultivation}

Effect of $\mathrm{Co}^{++}$addition. It was found from the results of preliminary experiments that higher concentrations of $\mathrm{Co}^{++}$in the medium up to $10^{-3} \mathrm{M}$ brought stronger activation effect. The addition of $10^{-3} \mathrm{M} \mathrm{Co}^{++}$exhibited a remarkable activating effect and that of $5 \times 10^{-5} \mathrm{M} \mathrm{Co}^{++}$ showed little effect on the activity of the cell. On the other hand, cell growth was strongly prevented in the presence of $2 \times 10^{-3} \mathrm{M} \mathrm{Co}^{++}$ Table I shows the activity and yield of the cells grown with or without the addition of $10^{-3} \mathrm{M} \mathrm{Co}^{++}$The cells grown with $\mathrm{Co}^{++}$ showed far more activity than the cells grown without $\mathrm{Co}^{++}$and this tendency appeared stronger in longer reaction time. Presumably this was due to the intensified heat tolerance of the enzyme produced under the presence of $\mathrm{Co}^{++}$, referring to the effect of $\mathrm{Co}^{++}$on the heat stability as reported previously. ${ }^{11}$ The effect of $\mathrm{Co}^{++}$addition was also observed on active $\mathrm{pH}$ range. The cells grown with $\mathrm{Co}^{++}$showed similar activity at both $\mathrm{pH} 9.0$ and 7.5, whereas the control cells showed higher activity at $\mathrm{pH} 9.0$ than at 7.5 .

In early experiments, cell growth under the presence of $10^{-3} \mathrm{M} \mathrm{Co}^{++}$was partly inhibited. However, this obstacle was overcome by an adaptive cultivation on potato agar slant containing $\mathrm{Co}^{++}\left(5 \times 10^{-4} \mathrm{M}\right)$ and thus the cells could be harvested with similar yield as the control.

Time of $\mathrm{Co}^{++}$addition. The effect of $\mathrm{Co}^{++}$ was influenced by the time of addition. Addition within 6 hours from the start of cultivation intensified the production of the enzyme similarly, but, after 12 hours, the effect decreased gradually. The results are shown in Table II.

TABLE 1. EFFECT OF $\mathrm{Co}^{++}$ADDITION

\begin{tabular}{|c|c|c|c|c|c|c|}
\hline \multirow[b]{3}{*}{$\mathrm{Co}^{++}$Addition } & \multirow[b]{3}{*}{ Final $\mathrm{pH}$ of medium } & \multirow[b]{3}{*}{ Cell yield* } & \multirow{2}{*}{\multicolumn{2}{|c|}{ Reaction, 3 hrs. }} & & \multirow[b]{2}{*}{$18 \mathrm{hrs}}$. \\
\hline & & & & & Reactic & \\
\hline & & & $\mathrm{pH} \overparen{9.0}$ & $\overline{\mathrm{pH}} 7.5$ & $\mathrm{pH} \widehat{9.0}$ & pH 7.5 \\
\hline 0 & 7.8 & 530 & 100 & 76 & 100 & 80 \\
\hline $10^{-3} \mathrm{M}$ & 7.0 & 280 & 180 & 180 & 215 & 211 \\
\hline
\end{tabular}

* mg dry wt./100 $\mathrm{ml}$ broth

** Figures are expressed as per cent of the activity at $\mathrm{pH} 9.0$ of the cell grown without Co ${ }^{++}$.

4) W. R. Fernell and H. K. King, Analyst, 78, $80(1953)$. 
TABLE II. EFFECT of THE TIME OF $\mathrm{Co}^{++}$ ADDITION

\begin{tabular}{|c|c|c|c|}
\hline & Coll rield & \multicolumn{2}{|c|}{ Activity, mg Fru/ml } \\
\hline $\mathrm{Co}^{++}$addition & $\mathrm{mg} / \mathrm{ml}$ & $\mathrm{pH} 9.0$ & $\widehat{\mathrm{pH}} 7.5$ \\
\hline $0 \mathrm{hr}$ & 580 & 39.7 & 37.7 \\
\hline 6 & 480 & 39.7 & 37.7 \\
\hline 12 & 530 & 32.9 & 31.1 \\
\hline 18 & 610 & 32.3 & 30.9 \\
\hline
\end{tabular}

Gultivation period: 24 hours

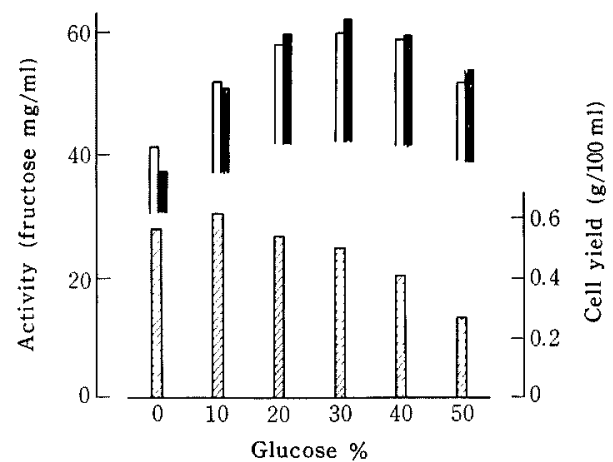

FIG. 1. Effect of Glucose Addition.

$\square$ Activity at $\mathrm{pH} 9.0$
"
Cell yield

Effect of glucose. When xylose in the medium was partly replaced with glucose, acceleration of enzyme production was observed, though cell yield was decreased gradually corresponding with the increase of glucose amount. As shown in Fig. 1, replacement of $30 \%$ of xylose with glucose was most effective and the activity of the cell was 1.5 times as strong as the control. A half amount of xylose could be substituted by glucose still with the improving effect on the activity per cell weight, but the total enzyme production decreased as a result of the diminution of cell yield. When intact cells are used as the enzyme source in the isomerization of glucose, it may be more favorable to diminish the amount of cell addition by using the cells of higher activity. Replacement of xylose with starch also showed similar effect, but the efficiency was smaller than with glucose.

\section{Cultivation in Jar Fermenter}

From the results of above experiments done with shaking cultivation, it was demonstrated that the enzyme production of the strain SK was remarkably stimulated by the addition of $\mathrm{Co}^{++}$and by a partial replacement of xylose as carbon source with glucose.

Generally it has been known that the results obtained from the shaking cultivation do not always coincide with the one from submerged cultivation with aeration and agitation. Therefore the experiments with shaking method were succeeded with following propagation experiments in jar fermenter.

Variation of $\mathrm{pH}$ during cultivation. It was revealed that the $\mathrm{pH}$ value of the media varies remarkably depending on the kind of the carbohydrate source. Aeration rate and addition of $\mathrm{Co}^{++}$also influenced the $\mathrm{pH}$ variation. Fig. 2 shows the variation of $\mathrm{pH}$ value of media containing xylose, glucose or starch as a sole carbon source, respectively. The $\mathrm{pH}$ value of the xylose medium shifted gradually to the alkaline side during the growth period, whereas the $\mathrm{pH}$ values of glucose and starch media showed a small rise at the first half period of growth and then lowered to the acid side, rather rapidly in glucose medium.

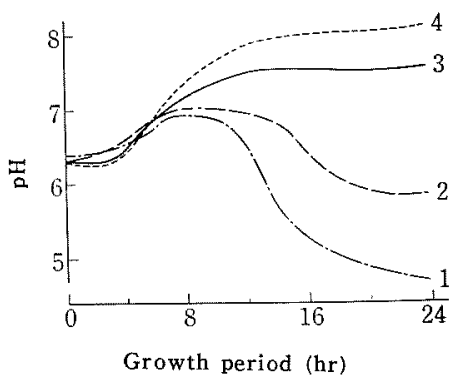

FIG. 2. Effect of Carbon Source on $\mathrm{pH}$.

Medium; 21 in 51 , fermenter

$$
\begin{aligned}
& \text { l; C source, glucose } 1 \% \\
& 2 ; " \text { starch " } \\
& 3 ; \quad \text { xylose " } \\
& 4 ; \quad \text { xylose " } \\
& 1 \sim 3 \text {; agitation } 200 \text { r.p.m., aeration } 61 / \text { min. } \\
& 4 ; \quad \text { " } 300 " \text { " } 10 "
\end{aligned}
$$




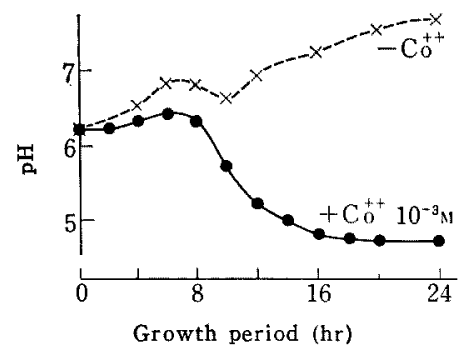

FIG. 3. pH Change in Xylose-Glucose Medium.

Medium; 121 in 301 fermenter

C source; Xylose $0.7 \%+$ Glucose $0.3 \%$

Aeration; $30 \mathrm{l} / \mathrm{min}$, Agitation; 100 r.p.m.

It is also seen that the strong aeration results in the high $\mathrm{pH}$ value of xylose medium.

From the results of shaking cultivation, it was found that the partial replacement of xylose in the medium with glucose stimulated the enzyme production. In Fig. 3 the change of $\mathrm{pH}$ value of the medium containing $0.7 \%$ of xylose and $0.3 \%$ of glucose as carbon source is shown. The $\mathrm{pH}$ value changed similarly as in the case of glucose medium shown in Fig. 2 and, after 24 hours of cultivation period, the final $\mathrm{pH}$ was 4.7. The cell yield was only $20 \mathrm{~g}$ per 121 of medium. The growth of this strain was suppressed at $\mathrm{pH}$ below 6.0. Therefore, it is apparently necessary to adjust $\mathrm{pH}$ during the growth period. Fig. 3 also shows the effect of the $\mathrm{Co}^{++}$addition on $\mathrm{pH}$ value. In the absence of added $\mathrm{Co}^{++}$, the $\mathrm{pH}$ value did not exhibit notable falling, conversely it showed gradual rise.

Relation among $\mathrm{pH}$ value, cell growth and activity. On the basis of the results mentioned above experiments of cultivation were carried out adjusting the $\mathrm{pH}$ value with an alkaline solution in order to prevent the $\mathrm{pH}$ falling below 6.0. In order to investigate the correlation among the $\mathrm{pH}$ value, growth and activity of the cell, three examples of cultivation, $\mathrm{A}, \mathrm{B}$, and $\mathrm{C}$, with which the modes of $\mathrm{pH}$ change were different from each other, were selected from many replicate cultivations. The results are shown in Fig. 4,5 and 6.

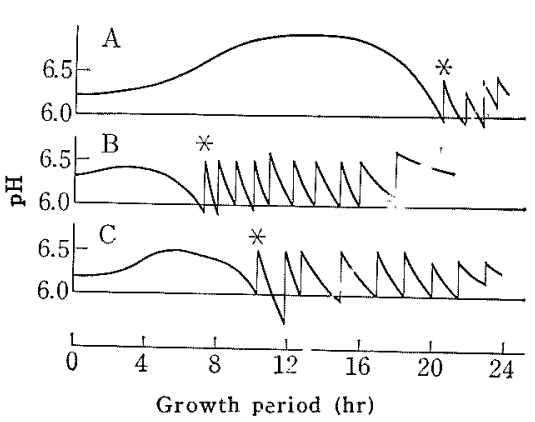

FIG. 4. $\mathrm{pH}$ Charge during Cultivation.

Medium; 151 in 30-1 fermenter

C source; xylose $0.7 \%+$ glucose $0.3 \%$

Aeration; $30 \mathrm{l} / \mathrm{min}$. with $\mathrm{A}$

$20 "$ with $\mathrm{B}$ and $\mathrm{C}$

Agitation; 200 r.p.m. with A

100 "with $\mathrm{B}$ and $\mathrm{C}$

Different batches of seed-culture were used as inocula for $\mathrm{A}, \mathrm{B}$, and $\mathrm{C}$.

* Start of pH adjustment.

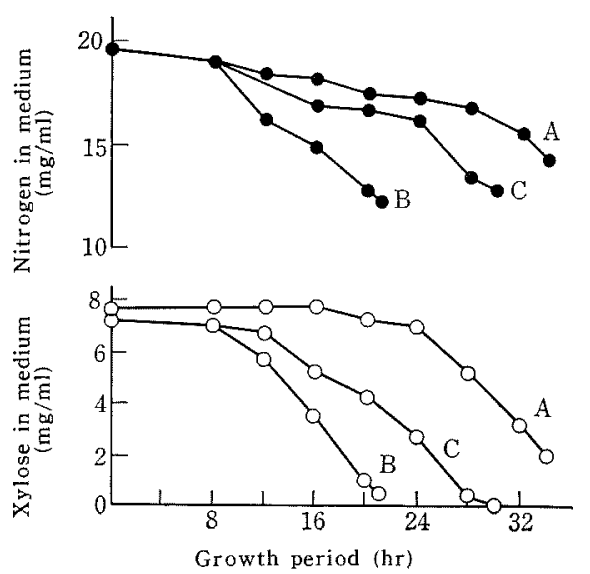

FIG. 5. Decrease in the Amounts of Nutrients in the Media.

A, B, and C; see the legend to Fig. 4.

Althohgh the culture conditions for $\mathrm{B}$ and $\mathrm{C}$ were the same, different batches of seedculture were used in these experiments, thus causing a considerable difference in the resulting cell growth, $\mathrm{pH}$ values, and enzyme activities. In $\mathrm{A}$ a rise of $\mathrm{pH}$ value at the early stage of growth period took a rather 


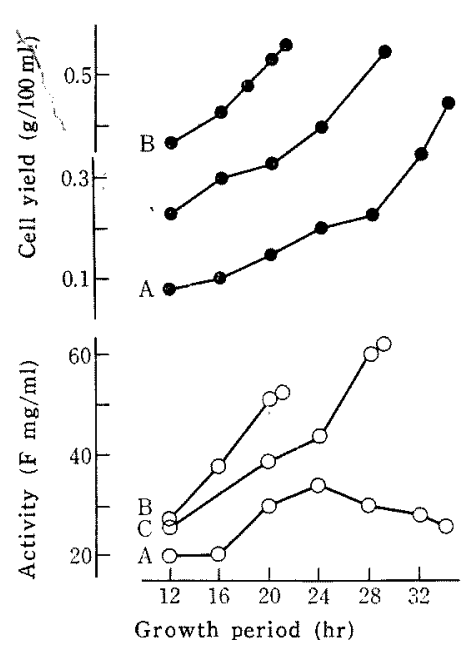

FIG. 6. Cell Yield and Activity.

long time and it was about 20 hours after the starting time to reach $\mathrm{pH}$ 6.0. On the other hand, the value in $\mathrm{B}$ went to $\mathrm{pH} 6.0$ within 8 hours through a small rise, and the behavior of $\mathrm{pH}$ in $\mathrm{C}$ was in the middle between $\mathrm{A}$ and B (Fig. 4). The decrease of nutrient in these cultivation media was corresponding with the lowering of $\mathrm{pH}$ value as shown in Fig. 5. That is, the consumption of nitrogen and carbon sources occurred rather rapidly during the period of $\mathrm{pH}$ adjustment after the termination of $\mathrm{pH}$ rise in the early stage, and so faster in the order of $\mathrm{B}, \mathrm{C}$ and $\mathrm{A}$. Accordingly, the time required to reach to some level of cell growth was shortest in the case of $\mathrm{B}$ and followed by $\mathrm{C}$. In the case of A, on the other hand, it took a rather long time to reach, a similar cell growth level to that of $\mathrm{B}$ or $\mathrm{C}$, and moreover, the cell havested after prolonged cultivation showed a declining enzyme activity (Fig. 6). Usually, in shaking cultivation with the medium containing a mixture of glucose and xylose as carbon source and $\mathrm{Co}^{++}$, the final $\mathrm{pH}$ value after 24 hrs of shaking was found to be $6.0 \sim 7.0$ through a drop in the course of cultivation, even without the adjustment. In submerged cultivation, however, it was necessary to adjust $\mathrm{pH}$ during cultivation period and the mode of $\mathrm{pH}$ change often varied as described above. These variations may partly depend on the rate of aeration and the mechanical effect of agitation, and also may be due to the subtle difference of the seed culture. The definite factors are not yet known. However, the above experiments suggest that the consumption of nutrients and hence the cell growth and enzyme production would occur efficiently at the period in which the $\mathrm{pH}$ value of medium shows declination to acid side. This was observed also in the experiment which compared the cultivations of two strains. Starting with similar conditions, the $\mathrm{pH}$ value of the medium inoculated with the strain No. 3105 did not show any significant drop but conversely exhibited a gradual rise whereas, in the cultivation of the strain SK, it needed to adjust it by alkali addition to prevent the lowering of $\mathrm{pH}$ value. Xylose consumption in each medium was fairly different, i.e., after 18 hours of cultivation the amounts of xylose consumed were $76 \%$ in the medium with the strain SK and $22 \%$ with the strain No. 3105 for instance. Accordingly, the rises of cell growth and enzyme production with the strain No. 3105 considerably delayed, although a prolonged cultivation of the strain No. 3105 did not deteriorate the enzyme activity and produced similar levels of enzyme activity and cell growth, after 32 hrs of cultivation, to the levels of the strain

\section{TABLE III. ISOMERIZATION IN a Concentrated} GLUCOSE SOLUTION
Cell added, \% (as dry matter)

$$
\begin{aligned}
& \mathrm{C} 1\left\{\begin{array}{l}
0.5 \\
1.0
\end{array}\right. \\
& \mathrm{C} 2\left\{\begin{array}{l}
0.5 \\
1.0
\end{array}\right.
\end{aligned}
$$

Fructose, $\%$ in total sugar

$\begin{array}{ll}24 \overbrace{\mathrm{hr}} & 48 \mathrm{hr} \\ 21.1 & 34.3 \\ 28.2 & 40.0 \\ 37.2 & 47.1 \\ 41.6 & 51.0\end{array}$

Reaction mixture: Glucose, 50\% (w/w); phosphate buffer $\mathrm{pH} 7.5,0.05 \mathrm{M}$ : $\mathrm{MgSO}_{4}, 0.02 \mathrm{M}$ and resting cell. The amounts of cells added are per cent to glucose weight.

C1: Cells grown on xylose

C2: Cells grown on xylose-glucose $(7: 3)$ mixture 
SK obtained by the cultivation of $24 \mathrm{hrs}$. the cell grown in the presence of $\mathrm{Co}^{++}$is Isomerization with concentrated glucose solu- shown in Table III. About a half amount of tion. As demonstrated previously, ${ }^{2 \prime}$ the glucose was converted into fructose within enzyme from the strain SK was not inhibited 48 hours at $60^{\circ} \mathrm{C}$ by the addition of the cell by the substrate glucose even in a concent- in an amount of $0.5 \%$ (as dry matter) of the rated solution such as 4 moles/l. The isomeri- glucose amount.

zation rate of $50 \%(\mathrm{w} / \mathrm{w})$ glucose solution by 